\title{
A NEW SPECIES OF THE GENUS COLEOSOIMA (ARANEAE: THERIDIIDAE) FROM JAPAN
}

\author{
Hajime Yoshida
}

7-18, Kagota 2-Chome, Yamagata, Yamagata 990, Japan

\section{Synopsis}

YoshidA, Hajime (7-18, Kagota 2-Chome, Yamagata, Yamagata 990, Japan): A new species of the genus Coleosoma (Araneae: Theridiidae) from Japan. Acta arachnol., 33 : 45-50 (1985).

A new species of the genus Coleosoma, C. margaritum, is described from Japan. A list of the Japanese species of the genus Coleosoma is also given.

The genus Coleosoma is distinguished from the other genera by male abdomen with a sclerotized ring covering anterior half of venter and a carina above.

Two species, Coleosoma blandum O. PICKARD-CAMBRIDGE and C. octomaculatum (BöSENBERG et STRAND), were recorded from Japan. The former species was first reported by OHNo and YAGINUMA in 1972 and afterward it was collected widely from warmer part of Japan. The latter one was transferred from Theridion by myself in 1982.

Recently, another species of this genus was collected by Y. CHIKUNI in Nagano and Iwate Prefectures, Japan. In my close examination, this species is recognized as a new species.

\section{Coleosoma margaritum n. sp.}

Male (Holotype). Total length $2.1 \mathrm{~mm}$. Carapace length $1.1 \mathrm{~mm}$; width 0.8 $\mathrm{mm}$. Abdomen length $1.2 \mathrm{~mm}$; width $0.8 \mathrm{~mm}$.

Measurements of legs as follows $(\mathrm{mm})$ :

\begin{tabular}{cccccc} 
& Fem. & Pat. \& Tib. & Met. & Tar. & Total \\
I & 1 & 2.4 & 1.8 & 0.7 & 6.9 \\
II & 1.3 & 1.4 & 1.1 & 0.5 & 4.3 \\
III & 0.9 & 0.9 & 0.7 & 0.4 & 2.9 \\
IV & 1.4 & 1.4 & 1.2 & 0.5 & 4.5 \\
\hline
\end{tabular}




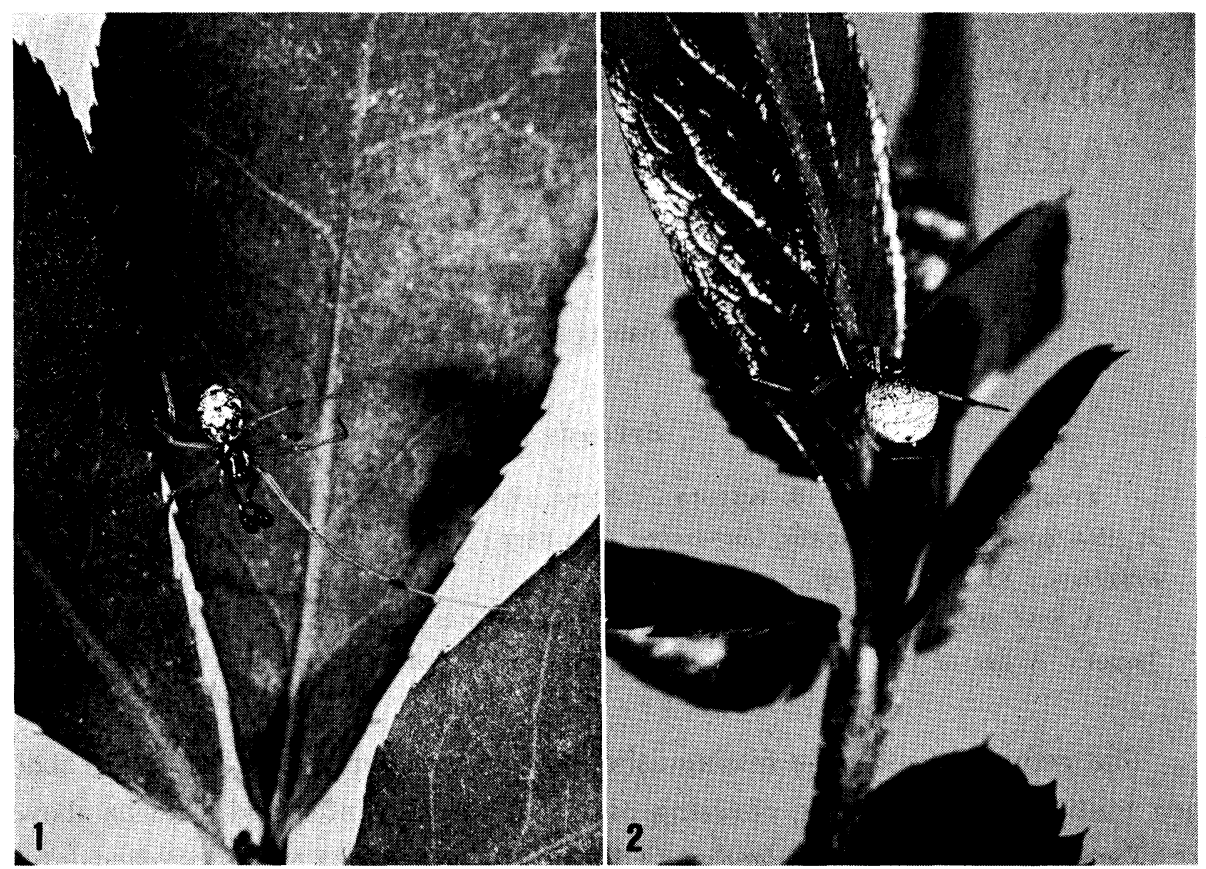

Figs. 1-2. Coleosoma margaritum n. sp. 1. Male, directly after ecdysis.

2. Female. [photo: Y. CHIKUNI]

Median eyes slightly smaller than laterals. AME smallest. AME 1.6 times their diameter apart. PME 0.9 time their diameter apart. Lateral eyes touching. Carapace oval with clypeus projecting and eye region projecting smoothly. Median depression circular distinctly. Chelicerae with one tooth on anterior margin. Maxillae large with pointed tip and globular base. Sternum triangular and pointed between fourth coxae. Abdomen suboval with the anterior sclerotized ring, which contains as a ventral shield and has a pair of lobes on dorsum. Palpal organ : conductor small; radix projecting; median apophysis large with two projections and large bulb which overlaps short embolus.

Carapace dark brown; eye region to cephalic depression dusky; marginal area dusky. Chelicerae, labium and maxillae dark brown. Sternum dark brown, dusky marginally. Palpus dark brown; tarsi blackish brown. Legs yellowish brown; first and fourth tibiae with distal blackish band. Abdomen grayish white with four pairs of white pigments and median, lateral and pairs of dorsal black flecks; sclerotized area dark brown.

Female (Paratype I). Total length $2.9 \mathrm{~mm}$. Carapace length $0.9 \mathrm{~mm}$; width 

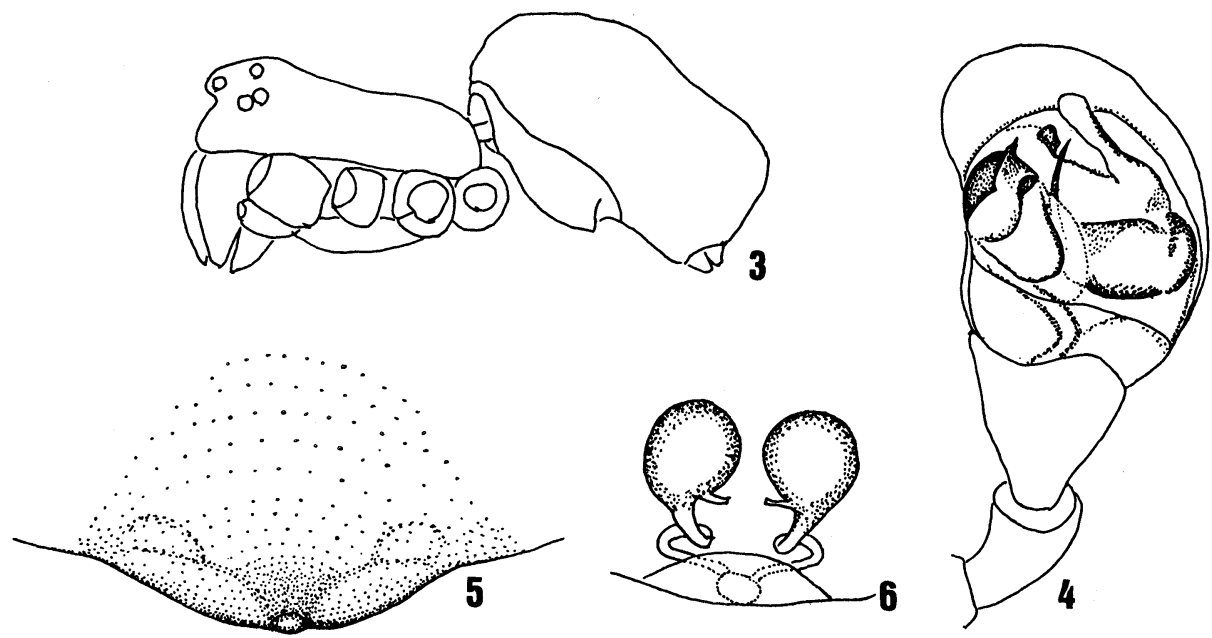

Figs. 3-6. Coleosoma margaritum n. sp. 3. Male, lateral view. 4. Male palpus, ventral view. 5. Female epigynum, ventral view. 6. Female genitalia, dorsal view.

$0.8 \mathrm{~mm}$. Abdomen length $1.9 \mathrm{~mm}$; width $1.9 \mathrm{~mm}$; hight $2.0 \mathrm{~mm}$.

Measurements of legs as follows (mm):

\begin{tabular}{ccclll}
\hline & Fem. & Pat. \& Tib. & Met. & Tar. & Total \\
\hline I & 1.8 & 1.9 & 1.55 & 0.65 & 5.9 \\
II & 1.2 & 1.1 & 0.9 & 0.5 & 3.7 \\
III & 0.9 & 0.8 & 0.65 & 0.4 & 2.75 \\
IV & 1.45 & 1.25 & 1 & 0.5 & 4.2 \\
\hline
\end{tabular}

Anterior eyes smaller than posterior. PME largest. AME one and a half diameters apart. PME two-thirds diameter apart. Carapace pear-shaped with circular median depression. Abdomen subglobular, slightly higher than long or wide.

Carapace dark brown with light parallel stripes. Chelicerae brown with longitudinal dark flecks. Labium and maxillae blackish brown. Sternum blackish brown, light centrally. Palpus yellowish brown with brown bands. Legs yellowish brown: patellae brown; first and fourth tibiae with basal and distal, and metatarsi with basal blackish bands. Abdomen covered with white pigments, and with some pairs and two median dark flecks; venter blackish brown with small white pigments between epigynum and spinnerets. 


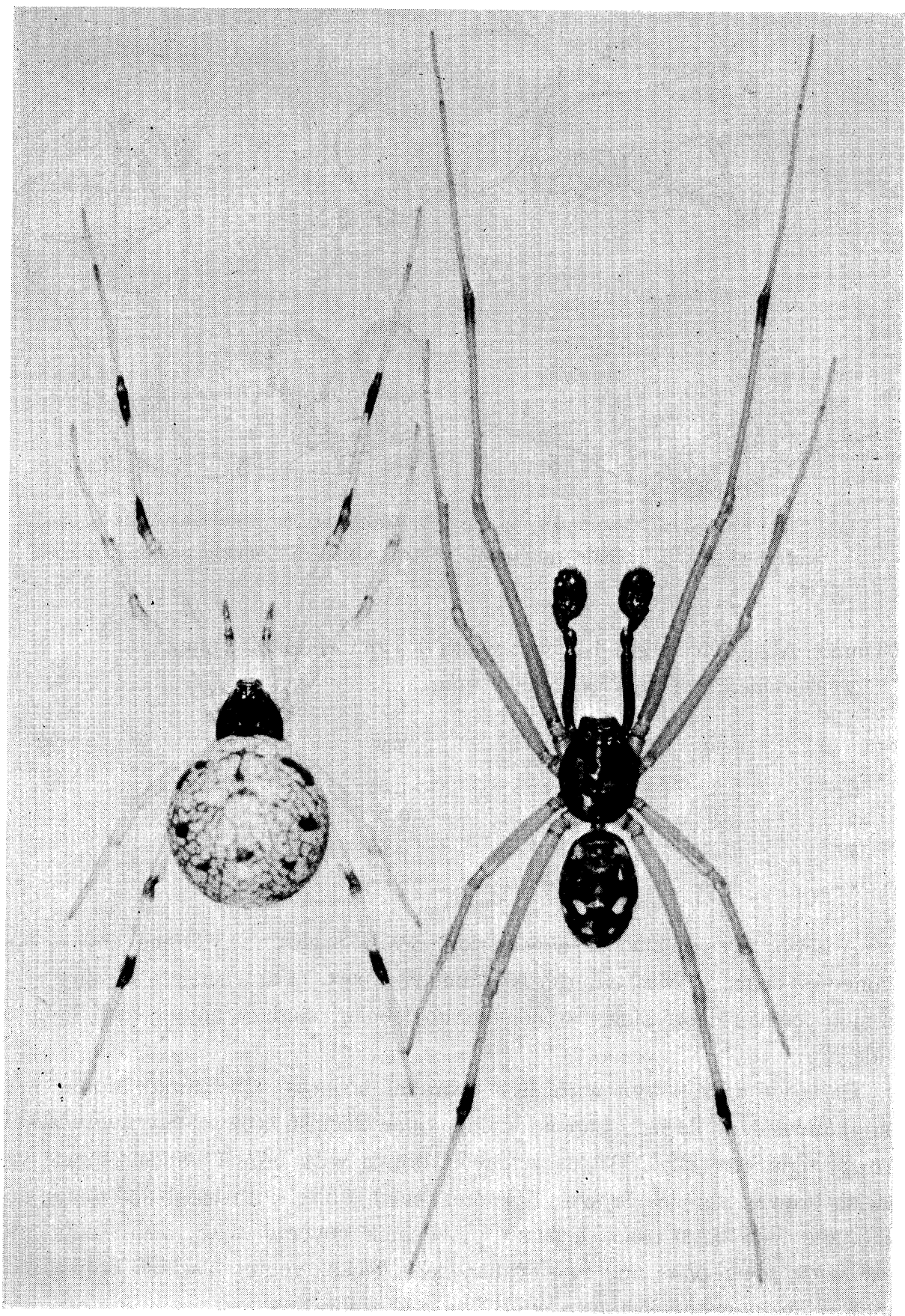


Type material. Holotype: $\hat{\delta}$, Iwahara, Horigane, Nagano Prefecture, Japan, 13-VII-1984, Y. CHIKUni (in the collection of the Arachnological Society of East Asia). Paratype I: 우, same data as holotype. Paratypes: 2 우, same data as holotype ; 1 으, riverside of Torikawa, Horigane, Nagano Prefecture, 22-VII-1976, Y. ChIKuni; 4§, Hosokura, Iwate Prefecture, 22-VI-1973, Y. ChIKUnI.

Distribution. Japan: Honshu (Iwate and Nagano Prefectures).

Remarks. This species is similar to Coleosoma octomaculatum (BösENBERG et STRAND), but distinguished from it by grayish white abdomen, and male palpal embolus short and median apophysis large with projections.

\section{A list of the Japanese species of the genus Coleosoma}

1. Coleosoma blandum O. PICKARD-CAmbridge, 1882

New record. Japan: Saga Pref., Fuji, H. Yoshida; Oita Pref., Oita, N. Kikuya, Tsukumi, N. Kikuya ; Kagoshima Pref., Amami-Oshima Is., Koniya, H. YoshidA; Okinawa Pref., Okinawa Is., Nago, H. YoshidA, Tokashiki Is., H. YoshidA, Ishigaki Is., Mt. Banna-dake, H. YoshIDA, Ishigaki Is., Kabira, H. YoshidA. Indonesia: Bali Is., Sanur, H. YoshidA.

Distribution. Japan (Honshu, Aogashima Is., Kyushu and the Ryukyus), Taiwan, Burma, Thailand, Indonesia, Ceylon and Seychelle.

2. Coleosoma octomaculatum (BöSENBERG et STRAND, 1906)

Distribution. Japan (Hokkaido, Honshu, Shikoku, Kyushu and the Ryukyus), Korea, China and Taiwan.

3. Coleosoma margaritum YosHIDA n. sp.

Distribution. Japan (Honshu).

\section{Acknowledgements}

I wish to express my hearty thanks to Prof. T. Yaginuma for his continuous guidance, and to $\mathrm{Mr}$. Y. CHIKUNI for offering valuable collections and excellent photographs. My thanks are also due to Miss C. OKuma and Mr. N. KiKuYa for loan of material.

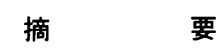

吉田 哉（テ990 山形市篭田 2 丁目 7 番18号)：日本産サヤヒメグモ属（真正クモ目：ヒメグモ 科) の 1 新種。

Fig. 7. Coleosoma margaritum n. sp., male (right) and female (left), dorsal view. [photo: Y. CHIKUNI] 
日本産のサヤヒメグモ属 Coleosoma の 1 新種, チクニサヤヒメグモ（新称）C. margaritumを 記載した。日本産としてはサヤヒメグモ C. blandum O. PICKARD-CAMBRIDGE，1882，ヤホシサ ヤヒメグモ C. octomaculatum (BöSENBERG et STRAND, 1906) についで 3 番目の種にあたる。

\section{References}

Bösenberg, W. \& E. Strand, 1906. Japanische Spinnen. Abh. senck. naturf. Ges., 30 : 93-422, pls. 3-16.

Ohno, M. \& T. Yaginuma, 1972. Materials for the distribution of Araneae in Japan (II). J. Toyo Univ., Gen. Educ. (N.S), 14:51-64. (In Japanese)

Pickard-Cambridge, O., 1882. On new genera and species of Araneida. Proc. zool. Soc. London, (1882) : 423-442, pls. 29-31.

Yoshida, H., 1982. Spiders from Taiwan III. Three species of the genera Coleosoma and Molione (Araneae: Theridiidae). Proc. Jap. Soc. syst. Zool., (24) : 37-40. 